\title{
Dokuz Eylül Üniversitesi İktisadi Ve İdari Bilimler Fakültesi Öğrencilerinin Kamu Harcama Algısı: Amprik Bir
}

\section{Analiz}

\author{
Haluk TANDIRCIOĞLU ${ }^{1}$
}

\author{
Fatma YAPICI ${ }^{2}$
}

$\ddot{O} z$

Bu çalı̧̧ma, Dokuz Eylül Üniversitesi İktisadi ve İdari Bilimler Fakültesi'nde öğrenim görmekte olan öğrencilerin kamu harcama algısını analiz etmek amacıyla yapılmıştır. Çalışma kapsamında elde edilen veriler IBM SPSS Statistics (24.0) programı kullanılarak analiz edilmiştir. Çalışmada yapılan, T Testi ve Tek Yönlü Varyans Analizi (ANOVA) sonucunda elde edilen bulgular çerçevesinde ankete katılan öğrencilerin cinsiyet, yaş, aile gelir düzeyi, bölümleri, sinıflarl, ailelerinin yaşadıkları yer ve ikamet ettikleri bölge açısından kamu harcamalarına yönelik algısı incelenmiştir.

Anahtar Kelimeler: Kamu Harcaması, Vergi, Bütçe, Harcama Algısl, Tek Yönlü Varyans Analizi, Bağımsız Örneklem T Testi.

Jel Sinıflandırma Kodları: H50, H61, H2O.

\section{Perceptions of Government Expenditures of the Students of Dokuz Eylül University Faculty of Economics and Administrative Sciences: An Amprical Analysis}

\begin{abstract}
In this study, applying the survey to students in Dokuz Eylül University Faculty of Economics and Administrative Sciences is measured perception of government expenditures of the students. The data derived are analyzed through the program IBM SPSS Statistics (24.0). In this study, has been examined perception of government expenditures of the students in terms of, participants' gender, age, department and class status, the place and region where their families live, the income level of their families in the framework of the findings obtained in the result of independent samples $t$ test and one-way analysis of variance (ANOVA).
\end{abstract}

Keywords: Government Expenditure, Tax, Budget, Perception of Government Expenditure, One Way Anova Analysis, Independent Samples $T$ Test.

JEL Classification Codes: H50, H61, H2O.

1 Dr. Öğr. Üyesi, Dokuz Eylül Üniversitesi, İ̈BF, Maliye Bölümü haluk.tandirci@deu.edu.tr

${ }^{2}$ Araş. Gör., Dokuz Eylül Üniversitesi, İIBF, Maliye Bölümü yapici.fatma@gmail.com 


\section{GİRIŞ}

\section{H.TANDIRCIOĞLU - F.YAPICI}

“Dokuz Eylül Üniversitesi İktisadi Ve İdari Bilimler Fakültesi Öğrencilerinin Kamu Harcama Algısı: Amprik Bir Analiz" konulu çalışmamızda öncelikle kamu harcaması, vergi ve kamu bütçesi gibi mali kavramlar açıklanmış, daha sonra kamu harcaması algısı ile ilgili yapılan amprik çalışmalara yer verilmiştir. Çalışmamızda kamu harcama algısını ölçebilmek için ana kütle olarak Dokuz Eylül Üniversitesi İktisadi ve İdari Bilimler Fakültesi'nde öğrenim görmekte olan 2-4. Sınıf öğrencilerini kapsayan 460 katılımcıya anket uygulanmıştır. Örneklem seçiminde kolayda örnekleme metodu kullanılmıştır. Uygulanan anket iki bölümden oluşmaktadır. Birinci bölümde DEU İ̈BF öğrencilerinin ve ailelerinin demografik özelliklerinin tespitine yönelik sorular yer almıştır. İkinci bölümde 5 likert ölçeği kullanılan 19 soru yer almıştır. Çalışmada daha sonra harcama algısını ölçmeye yönelik tanımlayıcı istatistiklere yer verilmiştir. Akabinde kamu harcama algısına etki eden faktörleri ilişkisine yönelik analiz sonuçları çalışmamızda yer almıştır. Çalışma kamu harcamalarına etki eden faktörlerin demografik özelliklere göre farklılık analizleri ve kamu harcama algısını etkileyen faktörlerin doğrusal regresyon analizi sonuçlarının ortaya konması ile son bulmuştur.

\section{KAMU HARCAMASI, VERGİ VE KAMU BÜTÇESİ}

Klasik devlet anlayışının hâkim olduğu dönemlerde tam kamusal mal ve hizmetlerin sunumu ile sınırlı tutulmaya çalışılan kamu harcamaları, Keynezyen yaklaşımın hakim olmasıyla giderek artmıştır. Kamu harcamaları bu değişimle beraber bir ekonomi ve sosyal politika aracı haline gelmiştir. Sosyal ve ekonomik hedeflerin gerçekleştirilmesinde devlete yüklenen sorumluluk arttıkça kamu harcamalarının da artırılması gerekli olmuştur. Keynes’in Genel Teorisi'nde sunmuş olduğu politikaların sonucu 
işsizlik sorununun yalnızca para politikası ile çözülemeyecek olup bayındırlık vb. alanlarda kamu harcamaları programlarının uygulanmasıyla çözülecek bir sorun olduğudur ( Patinkin, 1984: 98).

Ancak 1970' li yıllarda yaşanan stagflasyonist süreç keynezyen maliye politikası tedbirlerinin güvenirliğinin sorgulanmasını ve devlet müdahalesinin gerekliliğinin düşünülmesini gündeme getirmiştir. Milton Friedman ve Chicago Okulu ikinci kuşak iktisatçıları Keynes'in getirdiği kısa dönem odaklı analizleri eleştirerek hem kısa hem de uzun dönemli ekonomik analizlere önem vermiş ve devlet müdahalelerine ve kamu tekellerine karşı çıkmışlardır (Yay, 2001: 4) Bu yapı kamu harcamalarının nisbi önemini azaltsa da hiçbir zaman kamu harcamalarının düzeyi klasik iktisadın savunduğu ölçüde sınırlı olamamıştır.

Kamu harcamaları son dönemde yaşanan durgunluğa bağlı krizler de yine bir çözüm reçetesi olarak kullanılmıştır. Ancak buna rağmen devlet müdahalesine olan neo-liberal aforoz halihazırda süregelmektedir (Watkins, 2010: 476).Genel olarak iktisadi okullara göre değerlendirmesini yaptığımız kamu harcamaları farklı şekillerde tanımlanabilmektedir.

Kamu harcamaları kamu tüzel kişilerinin siyasi otoritelerini ve genel egemenlik haklarını kullanarak gerçekleştirdikleri harcamalardır (Devrim, 1998: 105). Kamu harcamaları dar anlamda ve geniş anlamda olmak üzere iki şekilde ele alınabilir. Dar anlamda kamu harcaması merkezi idare tarafından gerçekleştirilen kamu hizmetleri için yapılan harcamaları geniş anlamda kamu harcaması ise merkezi idare harcamalarına ilave olarak mahalli idare harcamaları, kamu iktisadi kuruluşları, sosyal güvenlik kuruluşlarının harcamalarını kapsamaktadır (Akdoğan, 2011: 61). 


\section{H.TANDIRCIOĞLU - F.YAPICI}

Harcamay1 gerçekleştiren birimin merkezi ya da mahalli olduğuna bakılmaksızın her koşulda harcamaların gerçekleşmesi bütçeler aracılığıyla gerçekleşmektedir. Bütçe kanunu ile devlet, topluma karşı yüklendiği çeşitli hizmetleri yerine getirmeye çalı̧̧akta bu amaçla mal ve hizmet üretiminde ve bu hizmetleri yerine getirebilmek için vergi, harç, borçlanma gibi çeşitli kamu gelirlerine ihtiyaç duymaktadır (Tüğen, 2017: 2). Diğer bir ifade ile kamu hizmetlerinin gelişmesi her şeyden önce bunları karşılayacak iktisadi ve mali kaynaklara bağlıdır (Erginay, 1987: 142). Dolayısıyla kamu harcamaları ile kamu gelirleri arasında yakın bir ilişki vardır. Kamu otoriteleri gerçekleştirdikleri kamu harcamalarını olabildiğince ayrıntılı şekilde paylaşmakta ve bu yolla kamu gelirlerini elde ederken karşılaştıkları olumsuz tepkileri azaltmaya çalışmaktadır.

Esasen vergi ve kamu harcaması ulusal düzeyde bir kolektif faaliyettir ve ulusal düzeyde aidiyet duygusu ile bağlantılı olması düşünülebilir (Çevik, 2012:280). Kamu harcama algısının artması aidiyet duygusunu geliştirecek ve kamu politika araçlarının kullanımındaki esneklik artmış olacaktır.

Devlet, anayasa ve yasalarca kendisine öngörülen işlevleri yerine getirmek üzere piyasalardan mal ve hizmet satın alır veya transferler gerçekleştirir. Devlet tarafindan sunulacak kamusal mal ve hizmetler seçim mekanizması içinde "oy" aracılığıyla belirlenir. Parlamenter demokrasilerde seçmenler seçim sürecinde kendisine en uygun gelen mal ve hizmet bileşimini vadeden siyasal partiye oy vererek aslında kamusal mal ve hizmetlere olan talebini açıklamış olur. Siyasal karar alma sürecinde yer alan seçmenler kendileri için yapılan kamu harcamalarını ve bu harcamaların finansmanı için kullanılan kamu gelirlerini olduğundan farklı algılayabilmektedir. Mevcut bu durum literatürde mali aldanma kavramı olarak geçmektedir. 
Dokuz Eylül Üniversitesi İktisadi ve İdari Bilimler Fakültesi Dergisi Cilt:33, Sayl:1, Yll:2018, ss. 261-292

Mali aldanma kavramı ilk defa Amilcare Puviani tarafindan açıklanmıştır. Buna göre mali aldanma vergi mükellefi olan seçmenlerin devlet tarafindan kendilerine sunulan bazı mal ve hizmetlere olan maliyetini tam olarak fark etmemeleri ve bu mal ve hizmetlere yönelik taleplerini sürekli olarak attırmaları olarak tanımlanmaktadır (Aktan ve Dileyici, 2014: 90). Mali aldanma, vergi aldanması ve harcama aldanması olarak iki yönde açıklanmaktadır. Aynı zamanda vergi mükellefi olan seçmenlerin kendilerine sunulan mal ve hizmetlerden kaynaklanan vergi yüklerini eksik algılamaları vergi aldanması olarak tanımlanırken, kişilerin kamusal mal ve hizmetlerden sağladıkları faydaları yanlış algılamaları harcama aldanması olarak açıklanmaktadır. (Aktan ve Dileyici, 2006: 176-177). Mali aldanma sınırlandırılamadığı takdirde kamu harcamaları ve kamu gelirlerinin bileşiminde sapmalar gerçekleşebilmektedir.

Sebebi ne olursa olsun kamu harcamaları ve kamu gelirleri her geçen gün artmakta ve uygulamacı birimler mali saydamlı ve hesap verme sorumluluğu çerçevesinde kendileri ile ilgili algıyı arttırmaya ve böylelikle siyasal karar alma sürecindeki desteklerini arttırmaya çalışmaktadır.

\section{LITERATÜR TARAMASI}

Türkiye'de kamu harcama algısı ile ilgili olarak yapılan amprik çalışmalar yeterli düzeyde değilken kamu gelirleri içerisinde yer alan vergilere karşı tutum ve davranışlarıyla ilgili çok fazla amprik çalışma yapıldığı görülmektedir. Ancak bu çalışmaların bir kısmında kamu harcama algısını ölçmeye yönelik sorular ve değerlendirmelerin yer aldığ görülmektedir. Bu durum vergilerle kamu harcamaları arasındaki ilişkiden kaynaklanmaktadır. Kamu harcamaları vergiler ile finanse edilmektedir. Vergi literatüründe mali bağlantı (fiscal connection) olarak bilinen bu ilişki, 


\section{H.TANDIRCIOĞLU - F.YAPICI}

kamu harcamasının gereğine inanan insanları, verginin gereğine de inanmaya zorlamaktadır (Siverekli ve Ertuğrul,2016:506).

Çiçek ve arkadaşları tarafindan 2008 yılı Güneydoğu Anadolu Bölgesi'nde Şanlıurfa, Diyarbakır, Mardin, Gaziantep ve Adıyaman vergi yükümlülerinin vergiyi algılama ve tutum analizini ölçmek amacıyla yapılan bir çalışması gerçekleştirilmiştir. 1361 mükellefin katılımının sağlandığ ankette yer alan "Ödediğiniz vergi ile devletten sağladığınız hizmet arasında doğru orantılı bir bağ kuruyor musunuz?" sorusuna katılımcıların \% 51.1'i hayır, \% 36.8'i zaman zaman ve \% 12.1'i evet yanıtını verilmiştir. Yine aynı çalışmada katılımcılar "Yükümlü olarak, devlet harcamalarının yöneldiği alanları ve yapılma şeklini izliyor ve bunları ödediğiniz vergilerle ilişkilendirerek değerlendirmede bulunuyor musunuz?" sorusunu \% 53.8 oranında izliyorum ve kendimce değerlendirmeler yapıyorum, \% 18.4’i yalnızca izliyorum, \% 17.6'si bu konuda bilgi sahibi değilim ve \% 10.2'i izlemiyorum şeklinde cevaplandırmışlardır (Çiçek vd, 2008: 75).

Çiçek tarafından 2006 yılında İstanbul ili içinde faaliyet gösteren vergi mükelleflerinin vergiye karşı tutumunu ve tepkilerini araştırmak amacıyla yapılan bir diğer çalışmada 502 vergi mükellefi yer almıştır. "Ödediğiniz vergi ile devletten sağladığınız hizmet arasında doğru orantılı bir bağ kuruyor musunuz?" sorusuna ankete katılanların \% 48,2'si hayır, \% 41,6's1 zaman zaman ve \%10,2'si ise evet yanıtını vermiştir (Çiçek, 2006: 138). Çiçek bu çalışmasında öne çıkan sonuçlardan birisi eğitim düzeyinin arttıkça kamu harcamalarının daha fazla, eğitim düzeyi düşük olanların ise kamu harcamalarının yapıldığ 1 alanları izleme ve değerlendirmede bulunma davranışını daha düşük olduğunu belirtmiştir.

Karakaş ve Çiçek tarafından (2009) Gaziantep'te yaşayan vergi mükellefleri ve KDV' ne muhatap olan tüketicilerden rastgele seçilmiş 470 
kişinin katıldığı anket çalışmasında yolsuzlukla ilgili tutum ve davranışların ölçülmesi hedeflenmiştir. Elde edilen sonuçlar Gaziantep'te yaşayan tüm vergi mükelleflerine genelleştirilmiştir. "Ödediğiniz vergi ile devletten aldığınız hizmet arasında doğru orantılı bir bağ kuruyor musunuz?" sorusuna katılımcıların \% 50'si hayır, \% 39,1'i zaman zaman ve \% 10,9'u evet yanıtını vermiştir. Kamu harcamalarını izleyip izlemediklerine ilişkin sorulan soruyu ankete katılanların \%54,5'i kendince kamu harcamalarını izlediğini ve değerlendirmeler yaptığını söyleyerek yanıtlamıştır. Diğer katılımcıların \% 23,0’ü kamu harcamalarını sadece izlediğini, \%13,4’ü bu konuda fikri olmadığını belirtirken \%9,1'i kamu harcamalarını izlemediğini ifade etmiştir. (Karakaş ve Çiçek, 2009: 57). Bu değerlendirmeden çıkan sonuç anketin uygulandığı kitlenin \%50' yi aşan kısmının kamu harcamalarını takip ettiğidir.

Kamusal harcamaların algılanmasına etki eden faktörleri tespit etmek amacıyla Demir (2009) tarafindan Ege Bölgesi il merkezlerinde küme örneklemesi yöntemiyle ana kütle sınırlandırılarak gerçekleştirilen ve 640 kişiye uygulanan ankete dayalı bir başka çalışmada ise "Ülkemizde kamu harcamalarında savurganlık yapılmaktadır" maddesi için katılımcıların yaklaşık \%88'i bu ifadeye katıldıklarını belirtmişlerdir. Ayrıca "Ödediğim verginin nerelere harcandığını bilmek benim için önemlidir” sorusuna ise çalışmaya katılanların yaklaşık \%95'i katılmıştır. Ankete katılanların \% 73'ü ödedikleri vergiyi ağır bulduklarını söylemişlerdir (Demir, 2009: 216). Demir bu çalışmasının sonucunda toplumsal kamu harcama algısına etki eden faktörler olarak kurumsal kalite, yolsuzluk algısı, mali bağlantı bilinç düzeyi, sübjektif vergi yükü, denetim, adalet ve eğitim faktörlerinin öne çıktığını tespit etmiştir. 


\section{H.TANDIRCIOĞLU - F.YAPICI}

Muter, Sakınç ve Çelebi tarafından gerçekleştirilen "Manisa İli Vergi Mükellefleri Üzerine Bir Anket Çalışması” isimli çalışmasında anketin uygulandığı alan olara Manisa merkez ilçe olarak belirlenmiştir. Denek kitle, kazanç ve iratların kaynağını oluşturan mesleki faaliyet gruplarına ayrılmış ve rastgele örnekleme yöntemiyle seçilen 505 kişiden oluşmaktadır. Ankette yer verilen sorular arasında yer alan "Mükellef olarak, devlet harcamalarının yöneldiği alanları ve yapılma şeklini izliyor ve bunları ödediğiniz vergilerle ilişkilendirerek değerlendirmede bulunuyor musunuz?" sorusuna "Yalnızca izliyorum" diyenler \% 32.3, "İzliyorum ve kendimce değerlendirmeler yapıyorum" diyenler \% 46.4 iken "İzlemiyorum” diyenler katılımcıların \% 9.5'i olarak tespit edilmiştir. "Bu konuda bilgi sahibi değilim" diyenlerin oranı \% 11.5 olurken bu soruyu cevapsız bırakanların yüzdesi \% 0.3 olmuştur. Ankete katılanların \%50’ye yakın bir kısmı kamu harcamalarını izlediğini ve değerlendirdiğini vurgulamıştır (Muter vd., 1993: 15). Çalışmadaki sonuçlara göre ankete katılanların büyük çoğunluğu kamu harcamalarını izlediğini ifade etmiştir.

Sağbaş ve Başoğlu Afyonkarahisar ilinde 2005 yılında İlköğretim çağındaki öğrencilerin vergi algısını ölçmeye yönelik olarak bir anket uygulaması gerçekleştirmiştir. Ankete ilköğretim, üç, dört, beş, altı, yedi ve sekizinci sınıfta öğrenimine devam eden 180 öğrenci katılmıştır. Çalışmaya katılan öğrenciler, ulaşılabilirlik kriterine göre seçilmiştir. Ankete katılanların vergiyi olumsuz algılamasının en önemli nedeni "alınan vergilerin doğru yere harcanmadığı düşüncesi" olarak tespit edilmiştir. Çalışma verginin nihai olarak kamu hizmetinin düzeyinin belirleyicilerinden olduğundan yola çıkılarak ilköğretim öğrencilerinde bu bilinci arttırmaya yönelik çözüm önerileri ile son bulmuştur. (Sağbaş ve Başoğlu, 2005: 138).

Siverekli ve Ertuğrul tarafından 2014 yılında Şanlıurfa'da bulunan Harran Üniversitesi çalışanlarına vergi mükellefleri/yükümlüleri olarak 
anket uygulaması yapılmıştır. Geçersiz olanlar gözardı edildiğinde 328 anket formunun girişi yapılmıştır. Ankete katılan yükümlülerin yaklaşık \%90’ı ödediği verginin nereye harcandığını bilmek istediğini ifade etmiştir. Söz konusu yükümlülerin önemli bir bölümü $(\% 58,3)$ kamu harcamalarını savurgan bulduğunu ve dolayısıyla ödedikleri verginin kamu hizmeti olarak geri dönmediği düşündüğünü $(\% 51,8)$ ifade etmiştir (Siverekli ve Ertuğrul, 2016: 506). Bu sonuçlardan hareketle ankete katılan yükümlülerin çoğunluğunun kamu harcamaları hakkında daha fazla bilgi sahibi olmak istediği söylenebilir.

Y1ldız ve Alkan tarafından 2016 yılında Kütahya Dumlupınar Üniversitesi İIBF'de öğrenimine devam eden öğrencilere uygulanan ve analize tabi tutulan 468 anketle katılımcı bütçeleme perspektifinden yükseköğretim öğrencilerinin bütçe algısı ölçülmüştür. Ancak bütçelemede etkinliğe ilişkin ifadelerin bulunduğu bütçelemede etkinlik faktörü ile ilgili önermelere (toplumsal taleplere uygun vergileme, kamu harcamalarının toplumsal taleplere uygun yapılması ve katılımcı bütçeleme sürecinin etkin uygulandığı) ankete katılanların katılımı düşük olmuş ve buna göre bütçe uygulama süreçlerine ilişkin etkinliğin zayıf olduğu görülmüştür. (Yıldız ve Alkan, 2017: 142).

\section{ARAŞTIRMANIN METODOLOJISİ}

Araştırma Dokuz Eylül Üniversitesi İktisadi ve İdari Bilimler Fakültesi'nde öğrenimine devam eden öğrencilerin kamu harcaması konusundaki algısını belirlemeyi amaçlamaktadır. Ana kütle Dokuz Eylül Üniversitesi İktisadi ve İdari Bilimler Fakültesi’nde öğrenim görmekte olan 2-4. Sınıf öğrencilerini kapsayan 460 katılımcıdan oluşmaktadır. Örneklem seçiminde kolayda örnekleme metodu kullanılmıştır. Anket iki bölümden oluşmaktadır. 
H.TANDIRCIOĞLU - F.YAPICI

Birinci bölümde DEU İIBF öğrencilerinin ve ailelerinin demografik özelliklerinin tespitine yönelik sorular yer almıştır. Bu grupta katılımcıların yaş aralıkları, gelir düzeyleri, aileleri ile birlikte yaşadıkları yer, ikamet ettikleri bölge, hangi bölümde ve kaçıncı sınıfta okuduklarına dair sorulara yer verilmiştir.

İkinci bölümde 5 likert ölçeği kullanılan 19 soru yer almıştır. Likert ölçeği soruları çok yetersiz/ yetersiz/ orta/ yeterli ve çok yeterli şekilde ve hiç katılmıyorum/ çok az katılıyorum/ orta düzeyde katılıyorum/ katılıyorum/ kesinlikle katılıyorum şeklinde sıralanarak kullanılmıştır. Uygulanan anketlerin sonunda toplam doneler SPSS 24. Program1 ile parametrik testler kullanarak analiz gerçekleştirilmiştir.

\section{ARASTIRMANIN BULGULARI}

Çalışma kapsamında Dokuz Eylül Üniversitesi İİB öğrencilerinden kolayda örnekleme metodu ile belirlenmiş örneklemden elde edilen veriler hem demografik hem de kamu harcama algısını ölçmeye yönelik olarak belirlenmiş sorulara ve değerlendirmelere dayanmaktadır. Örneklemden elde edilen demografik değişkenlere ilişkin frekans ve geçerli yüzde bilgileri verildikten sonra kamu harcama algısına yönelik olarak belirlenen faktörlerin tanımlayıcı istatistiklerine yer verilecektir.

\subsection{Demografik Değișkenler}

Anketimize katılanlara ilişkin elde ettiğimiz yaş, cinsiyet, ailenin gelir düzeyi, ailenin yaşadığı yer, ikamet edilen bölge ve sınıf bilgilerini içeren demografik özelliklere ait frekans ve geçerli yüzde dağılımları Tablo 1'de gösterilmektedir.

"Dokuz Eylül Üniversitesi İktisadi ve İdari Bilimler Fakültesi Öğrencilerinin Kamu Harcama Algısı” isimli çalışmamızda DEÜ İİBF Maliye Bölümündeki ve diğer bölümlerdeki öğrencilerden örnekleme 
Dokuz Eylül Üniversitesi İktisadi ve İdari Bilimler Fakültesi Dergisi Cilt:33, Sayl:1, Yll:2018, ss. 261-292 yoluyla seçilen 460 öğrenci anketimize katılmıştır. Bu öğrencilerin \% 35,4’ü 2. Sinıf, \% 23,5 ‘i 3. Sınıf ve \% 41,1’i 4. Sinıf öğrencisidir.

Tablo 1. Demografik Özellikler Frekans Tablosu

\begin{tabular}{|c|c|c|c|}
\hline & & Frekans & Geçerli Yüzde \\
\hline \multirow{5}{*}{ Yaş } & $18-20$ & 32 & 7,0 \\
\hline & $20-22$ & 210 & 45,7 \\
\hline & $22-24$ & 183 & 39,8 \\
\hline & $24-26$ & 32 & 7,0 \\
\hline & 26 üstü & 3 & 0,7 \\
\hline \multirow{2}{*}{ Cinsiyet } & Kadın & 253 & 55,0 \\
\hline & Erkek & 207 & 45,0 \\
\hline \multirow{5}{*}{ Ailenin Gelir Düzeyi } & 1500'den az & 64 & 13,9 \\
\hline & 1500-3000'den az & 242 & 52,6 \\
\hline & 3500-5000'den az & 116 & 25,2 \\
\hline & 5000-7000'den az & 25 & 5,4 \\
\hline & 7000 ve üstü & 13 & 2,8 \\
\hline \multirow{5}{*}{ Ailenin Yaşadığı Yer } & Köy-Kasaba & 52 & 11,3 \\
\hline & İlçe & 149 & 32,4 \\
\hline & $\dot{\mathrm{I}} 1$ & 94 & 20,4 \\
\hline & Büyükşehir & 162 & 35,2 \\
\hline & Yurtd1ş1 & 3 & 0,7 \\
\hline \multirow{7}{*}{ İkamet Edilen Bölge } & Marmara & 66 & 14,3 \\
\hline & Ege & 247 & 53,7 \\
\hline & İç Anadolu & 48 & 10,4 \\
\hline & Akdeniz & 14 & 3,0 \\
\hline & Güneydoğu Ana. & 49 & 10,7 \\
\hline & Karadeniz & 36 & 7,8 \\
\hline & Marmara & 66 & 14,3 \\
\hline \multirow{3}{*}{ Sinıf } & $2 . \sin 1 f$ & 163 & 35,4 \\
\hline & 3.sinif & 108 & 23,5 \\
\hline & 4.sinif & 189 & 41,1 \\
\hline \multicolumn{2}{|c|}{ Toplam } & 460 & 100,0 \\
\hline
\end{tabular}




\section{H.TANDIRCIOĞLU - F.YAPICI}

Ankete katılanların \% 81,5'i 20-24 yaş aralığında olmak üzere \% 55'inin kadın olduğu görülmektedir. Ankete katılanların \% 52,6's1 aileleri 15003000'den az gelir elde eden öğrencilerden oluşmakta iken aileleri 5000 ve üzeri gelir elde edenlerin payı ise \% 8,2'dir. Çalışmaya katılanların ikamet ettikleri bölgeler arasında en fazla yoğunlaşılan bölge \% 53,7 ile Ege Bölgesi'dir. Bunu sırasıyla Marmara (\%14,3) ve İç Anadolu (\% 10,4) Bölgeleri takip etmektedir. Ankete katılanların ailelerinin yaşadığı yer mülki birimler açısından değerlendirildiğinde; köy ve kasabalarda yaşayanların yüzdesi 11,3 iken il, ilçe ve büyükşehirlerde yaşayanların toplamı \% 88 olarak gözlemlenmiştir.

Demografik özelliklere ilişkin genel değerlendirmelerden sonra kamu harcama algısını ortaya koyacak tanımlayıcı istatistikler aşağıda yer alacaktır.

\subsection{Kamu Harcama Algısını Ölçmeye Yönelik Tanımlayıcı İstatistikler}

Tablo 2' de anket çalışmamızın ikinci kısmında yer alan likert ölçeğine göre hazırlanan sorularla, öğrencilerin, kendilerine en yakın buldukları seçeneği işaretlemek suretiyle verdikleri cevaplara bağlı olarak hesaplanan aritmetik ortalamaların ve standart sapmaların gösterildiği tanımlayıcı istatistiklere yer verilmiştir.

Tablo 2. Kamu Harcama Algısını Ölçmeye Yönelik Tanımlayıcı İstatistikler

\begin{tabular}{|c|l|c|c|c|c|c|}
\hline \multicolumn{7}{|c|}{ Tanımlayıcı İstatistikler } \\
\hline \multirow{2}{*}{$\begin{array}{l}\text { İletişim } \\
\text { Düzeyi }\end{array}$} & $\begin{array}{l}\text { Merkezi idare bütçesi } \\
\text { açık ve anlaş1lırdır }\end{array}$ & $\begin{array}{l}\text { Sazı } \\
\text { Yazılı ve ve görsel } \\
\text { basında bütçeyle ilgili } \\
\text { yeterince } \\
\text { paylaşılmaktadır haber }\end{array}$ & $\begin{array}{l}\text { Std. } \\
\text { Sap. }\end{array}$ & $\begin{array}{c}\text { Grup } \\
\text { Ort. }\end{array}$ & $\begin{array}{l}\text { Grup } \\
\text { Std.Sap. }\end{array}$ \\
\hline & 2,58 & 0,95 & & \\
\hline
\end{tabular}


Dokuz Eylül Üniversitesi İktisadi ve İdari Bilimler Fakültesi Dergisi

Cilt:33, Sayl:1, Yll:2018, ss. 261-292

\begin{tabular}{|c|c|c|c|c|c|c|}
\hline & $\begin{array}{lr}\text { Yazılı ve } & \text { görsel } \\
\text { basınının bütçe ile ilgili } \\
\text { haberleri } \\
\text { harcamalarına } \\
\text { duyarlılığı } \\
\text { yönde etkilemektedir }\end{array}$ & 460 & 2,51 & 1,08 & \multirow[t]{4}{*}{2,63} & \multirow[t]{4}{*}{0,56} \\
\hline & $\begin{array}{lr}\text { Kamu } & \text { harcamaları } \\
\text { konusunda } & \text { kamu } \\
\text { birimleri } & \text { tarafindan } \\
\text { yapılan } & \\
\text { bilgilendirmeler }\end{array}$ & 460 & 2,44 & 0,94 & & \\
\hline & $\begin{array}{lr}\text { Ailenizin } & \text { yaşadığ1 } \\
\text { yerde } & \text { kamu } \\
\text { harcamalarının } & \text { düzeyi } \\
\text { yüksektir } & \end{array}$ & 460 & 2,75 & 0,86 & & \\
\hline & $\begin{array}{lr}\text { Sosyal } & \text { medya } \\
\text { kullanımının } & \text { kamu } \\
\text { harcamaları } & \text { hakkında } \\
\text { algıyı etkilemektedir }\end{array}$ & 460 & 3,26 & 1,12 & & \\
\hline \multirow{2}{*}{$\begin{array}{c}\text { Bütçe } \\
\text { Duyarlılığı }\end{array}$} & $\begin{array}{ll}\text { Yazılı ve } & \text { görsel } \\
\text { basınının bütçe } & \text { ilgili } \\
\text { haberlerine } & \text { İIBF } \\
\text { öğrencileri duyarlıdır }\end{array}$ & 460 & 2,70 & 0,91 & \multirow[t]{2}{*}{2,43} & \multirow[t]{2}{*}{0,64} \\
\hline & $\begin{array}{l}\text { İİBF öğrencilerinin } \\
\text { bütçe sürecine ilgi } \\
\text { düzeyi yüksektir }\end{array}$ & 460 & 2,60 & 0,88 & & \\
\hline $\begin{array}{c}\text { Müdahaleci } \\
\text { Anlayış }\end{array}$ & $\begin{array}{lr}\text { Kamu } & \text { kesiminde } \\
\text { etkinlik } & \text { sağlamak için } \\
\text { kamu } & \text { harcamaları } \\
\text { sınırlandırılmalıdır. }\end{array}$ & 460 & 2,55 & 1,15 & 3,13 & 0,67 \\
\hline \multirow{3}{*}{ Eğitim } & 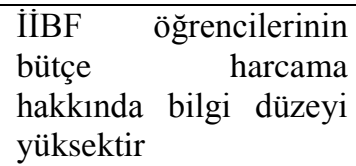 & 460 & 2,65 & 0,79 & & \multirow[b]{3}{*}{0,57} \\
\hline & $\begin{array}{lr}\text { İİBF } & \text { öğrencilerinin } \\
\text { mükellef } & \text { hakları } \\
\text { hakkında bilgi } & \text { seviyesi } \\
\text { yüksektir }\end{array}$ & 460 & 2,48 & 0,80 & & \\
\hline & $\begin{array}{l}\text { Aldığınız dersler kamu } \\
\text { maliyesiyle ilgili temel } \\
\text { bilgileri kapsamaktadır }\end{array}$ & 460 & 3,25 & 0,92 & 3,10 & \\
\hline
\end{tabular}




\section{H.TANDIRCIOĞLU - F.YAPICI}

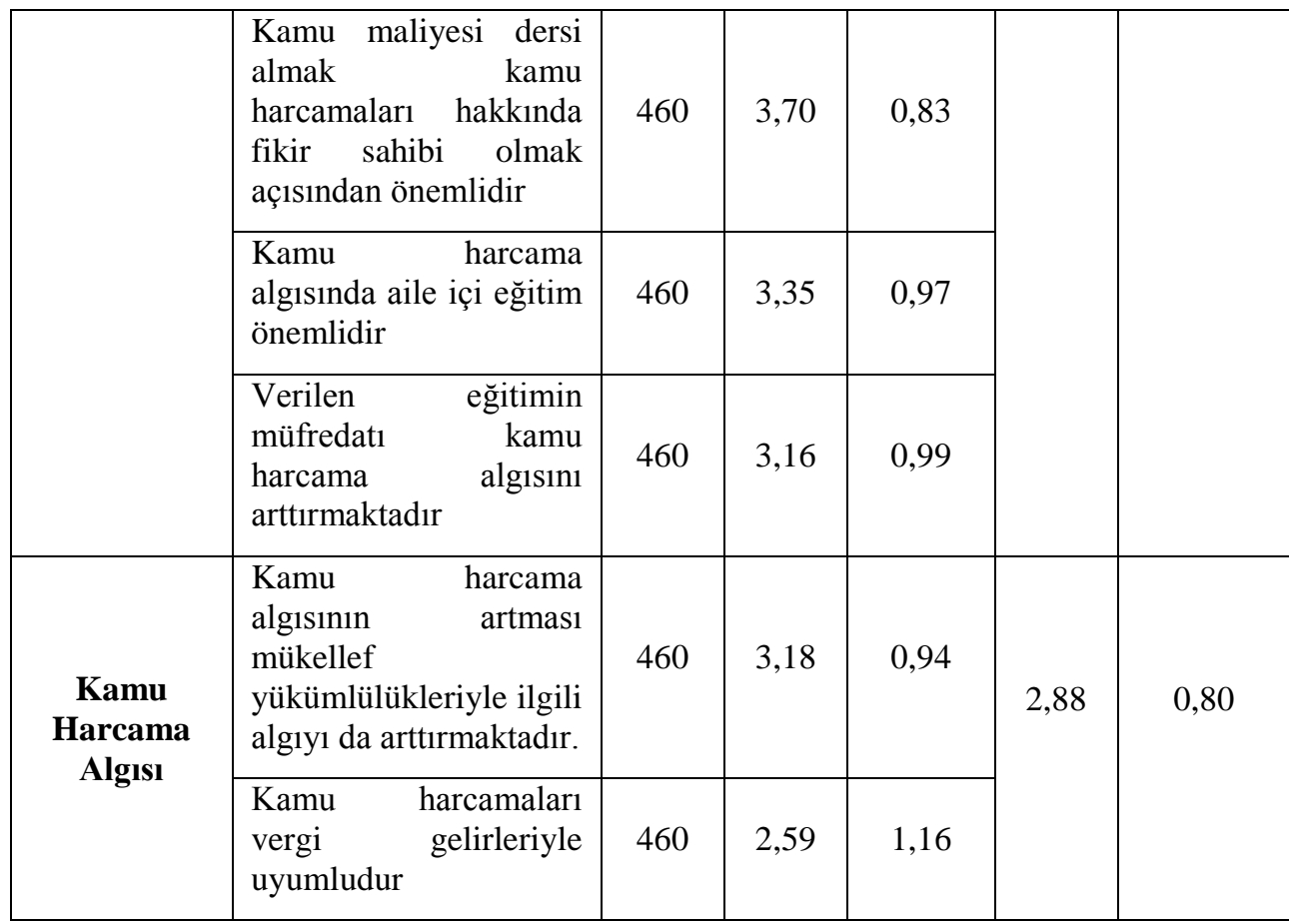

Çalışmaya katılanların ankette yer alan Likert ölçekli sorulara verdikleri yanıtlara göre kamu maliyesi dersi almanın kamu harcamaları hakkında fikir sahibi olmak yönünden önemli olduğu düşüncesi 3,70 aritmetik ortalamayla en yüksek ortalama olarak gözlemlenmiştir. Sosyal devlet anlayışının kamu harcamasını arttırması gerektiğini düşüncesi 3,69 aritmetik ortalamayla tespit edilmiştir. Aile içi eğitimin önemli olduğu düşüncesi 3,35 aritmetik ortalamayla tabloda öne çıkmaktadır.

Çalışmaya katılanların kamu harcama algısına yönelik sorulara göre kamu harcama algısının artmasının mükellef yükümlülükleriyle ilgili algıyı arttırdığına dair net hükümleri bulunmamaktadır. Tablo 2' de yer alan "Kamu harcamaları vergi gelirleriyle uyumludur" sorusuna katılımcıların verdikleri cevaplara göre aritmetik ortalama 2,59 olarak bulunmuştur. $\mathrm{Bu}$ aritmetik ortalamaya göre kamu harcamalarının vergi gelirleriyle uyumlu olduğu ankete katılanlar tarafından çok fazla kabul görmemektedir. Esasen 
bu durum kamu kesiminin vergi tahsilatını olumsuz yönde etkileyen temel unsurların başında gelmektedir. Toplanan vergilerin kamu harcaması olarak kendisine döneceğine dair kanaati düşük olan mükellef vergi ödevini yerine getirirken hassas davranmayacaktır. Kamu harcamalarıyla vergiler arasındaki ilişki ne kadar açık hale getirilirse uzun dönemde vergi hasılatı da o kadar yüksek olacaktır. Ankete katılanların doğrudan gelir vergisi mükellefiyetleri bulunmasa da dolaylı vergiler nedeniyle iktisadi mükellefiyetleri bulunduğundan vergisel yükümlülükler ile elde edilen kamusal hizmet arasında ilişki kurabildikleri varsayılmaktadır.

Kamu harcaması algısına etki eden faktörleri çalışmamızdaki sorular itibariyle gruplandırdığımızda iletişim düzeyi, bütçe duyarlılığı, müdahaleci yaklaşım ve eğitim şeklinde dört ana başlıkta toplamak mümkündür.

İletişim araçlarından en üst düzeyde yararlanan grubun içinde yer alan anket katılımcılarının yazılı ve görsel basında ve sosyal medyada yer alan bütçe ile ilgili haberlere yönelik algılarının 2,63 aritmetik ortalama ile çok yüksek olmadığı tespit edilmektedir. Ankete katılanlara göre kamu harcamalarıyla ilgili bilgilendirmeler, kamu harcamalarının düzeyi ile kamu harcamalarının açıklık ve anlaşılırlık düzeyi yeterli değildir.

Bütçe duyarlılığına yönelik sorularla ilgili değerlendirmeler sonucunda duyarlılığın 2,43 aritmetik ortalaması ile iletişim düzeyinin aritmetik ortalamasından düşük olduğu görülmektedir. $\mathrm{Bu}$ durumun hem anket katılımcılarının bütçe haberlerine ilgisizliğinden hem de bütçe ile ilgili haberlerin toplumun bütününe ve daha özelde ise gençlere yeterince aktarılmamasından kaynaklandığı söylenebilir.

Müdahaleci yaklaşım gruplandırmasına göre aritmetik ortalama 3,13 ile ortalamanın üzerinde yer almaktadır. Etkinliği sağlamak için devletin 


\section{H.TANDIRCIOĞLU - F.YAPICI}

sınırlandırılması görüşü ankete katılanlar tarafından $\% 46,6$ geçerli yüzdeyle kabul görmemiştir. Ancak \% 53,4’ ü ise devletin sınırlandırılmasını kabul etmektedir. Bütün bunlar değerlendirildiğinde örneklem içinde bulunan DEÜ İ̈BF öğrencilerinde sosyal devlet anlayışının genel kabul gördüğü ancak etkinliğin de göz ardı edilmediği görülmektedir.

Eğitime yönelik soru grubundaki aritmetik ortalama 3,10 olarak tespit edilmiştir. Öğrencilerin almış oldukları maliye müfredatını ilgilendiren dersler, aile içi eğitim ve diğer eğitim ve ögretim kanalları sayesinde sahip oldukları mali bilgilerin kamu harcama algılarını arttırmada yeterli olduğu değerlendirmesinde bulunmuşlardır. Ancak söz konusu bileşenleri içeren soruların oluşturduğu eğitim grubunda hesaplanan ortalama 3,10'dur. $\mathrm{Bu}$ ortalamanın çok yüksek düzeyde bir olumlu yargıya işaret etmediği de açıktır.

\subsection{Kamu Harcama Algısına Etki Eden Faktörleri İlişkisine Yönelik}

\section{Analiz Sonuçlar}

Kamu harcamaları algısına etki eden faktörlerin ana gruplar halinde tanımlayıcı istatistikleri Tablo 3'te verilmiştir. Kamu harcaması algısı üzerinde etkili olduğunu varsaydığımız iletişim, bütçe duyarlılığı, müdahaleci anlayış ve eğitim ana grupları arasında korelasyon analizi yapılmış olup gruplar arasındaki korelasyon Tablo 4'te verilmiştir.

$\mathrm{H}_{0}$ : Kamu harcama algısının belirleyicileri arasında ilişki yoktur $(\mathrm{r}=0)$

$\mathrm{H}_{1}$ : Kamu harcama algısının belirleyicileri arasında ilişki vardır $(\mathrm{r} \neq 0)$ 
Dokuz Eylül Üniversitesi İktisadi ve İdari Bilimler Fakültesi Dergisi Cilt:33, Sayl:1, Yll:2018, ss. 261-292

Tablo 3. Faktörler Arasında Pearson Korelasyon Katsayıları

\begin{tabular}{|l|c|c|c|c|c|}
\hline & $\begin{array}{c}\text { Kamu } \\
\text { Harcama } \\
\text { Algısı }\end{array}$ & İletişim & $\begin{array}{c}\text { Bütçe } \\
\text { Duyarlılı̆̆ı }\end{array}$ & $\begin{array}{c}\text { Müdahaleci } \\
\text { Anlayış }\end{array}$ & Ě̆itim \\
\hline $\begin{array}{l}\text { Kamu Harcama } \\
\text { Algısı }\end{array}$ & 1 &, $463^{* *}$ &, $350^{* *}$ &, $200^{* *}$ &, $361^{* *}$ \\
\hline İletişim & 1 &, $491^{* *}$ &, $210^{* *}$ &, $461^{* *}$ \\
\hline $\begin{array}{l}\text { Bütçe } \\
\text { Duyarlılığı }\end{array}$ & & & 1 &, $134^{* *}$ &, $544^{* *}$ \\
\hline $\begin{array}{l}\text { Müdahaleci } \\
\text { Anlayış }\end{array}$ & & & & 1 &, $103^{*}$ \\
\hline Eğitim & 460 & 460 & 460 & 460 & 460 \\
\hline Sayı & & & & & 1 \\
\hline
\end{tabular}

**Korelasyon 0.01 seviyesinde anlamlıdır. *Korelasyon 0.05 seviyesinde anlamlıdır.

Tablo 4'te verilen basit korelasyon analizine göre kamu harcama algısı belirleyicileri arasında birbirinden farklı ilişki düzeyleri olduğu görülmektedir. Eğitim ile bütçe duyarlılığı arasında korelasyon katsayısı (r=0,544) \% 99 güvenle anlamlıdır. İletişim ile bütçe duyarlılığı arasında korelasyon katsayısı (r=0,491) \% 99 güvenle anlamlıdır. İletişim ile kamu harcama algısı arasında bütçe duyarlılığında olduğu gibi korelasyon katsayısı (r=0,461) olmak üzere aralarında pozitif yönlü bir ilişki bulunmaktadır. Müdahaleci anlayış ile diğer değişkenler arasında pozitif yönlü bir ilişki bulunmakla birlikte anlam düzeyi düşüktür.

\subsection{Kamu Harcamalarına Etki Eden Faktörlerin Demografik Özelliklere} Göre Farklıık Analizleri

Kamu harcamalarına etki eden faktörler olarak belirlediğimiz iletişim düzeyi, bütçe duyarlılığı, müdahaleci anlayış ve eğitim faktörlerinin demografik özelliklere göre farklılık gösterip göstermediği bağımsız 


\section{H.TANDIRCIOĞLU - F.YAPICI}

örneklem t-testi ve tek yönlü varyans analizleri ile test edilmiş̧ir. Demografik özelliklere göre farklılık gösteren faktörlerle ilgili analiz sonuçlarına çalışmamızın bundan sonraki bölümlerinde yer verilmiştir.

\subsection{1. İletişim Düzeyi}

Kamu harcama algısına etki eden faktörler arasında değerlendirdiğimiz iletişim düzeyiyle ilgili kurmuş olduğumuz hipotez aşağıda verilmiştir.

$\mathrm{H}_{0}=$ Öğrencilerin yaşlarının iletişim düzeyine etkisi yoktur.

$\mathrm{H}_{1}=$ Öğrencilerin yaşlarının iletişim düzeyi etkisi vardır.

Tek yönlü varyans analizi sonuçlarına göre $\mathrm{p}=0,024<\alpha=0,05$ olduğu için $\mathrm{H}_{0}$ reddedilir, dolayısıyla $\mathrm{H}_{1}$ kabul edilir. Buna göre öğrencilerin yaşlarına göre iletişim düzeyi hakkındaki düşünceleri değişmektedir. İletişim düzeyi üzerine en yüksek algıya sahip olan öğrenciler 18-22 yaş grubunda yer almaktadır. Ancak yaş grupları arasındaki fark $\alpha=0,05$ düzeyinde anlamı değildir.

Tablo 4.Tek Yönlü Varyans Tanımlayıcı İstatistikleri

\begin{tabular}{|l|c|c|c|c|}
\hline \multicolumn{3}{|c|}{ İletişim Düzeyi } \\
\hline $18-20$ & Sayı & Ortalama & F & P \\
\hline $20-22$ & 32 & 2,7240 & \multirow{2}{*}{2,837} & \multirow{2}{*}{0,024} \\
\hline $22-24$ & 210 & 2,6952 & \\
\cline { 1 - 2 } $24-26$ & 183 & 2,5647 & & \\
\hline 26 üstü & 32 & 2,4479 & \\
\hline Toplam & 3 & 2,2222 & \\
\hline
\end{tabular}

\subsubsection{Bütçe Duyarlılığı}

Kamu harcama algısına etki eden faktörler arasında değerlendirdiğimiz bütçe duyarlılığı ile ilgili kurmuş olduğumuz hipotezler aşağıda verilmiştir. 
Dokuz Eylül Üniversitesi İktisadi ve İdari Bilimler Fakültesi Dergisi

Cilt:33, Sayl:1, Yll:2018, ss. 261-292

$\mathrm{H}_{0}=$ Öğrencilerin okudukların bölümlerin bütçe duyarlılığına etkisi yoktur.

$\mathrm{H}_{1}=$ Öğrencilerin okudukların bölümlerin bütçe duyarlılığına etkisi vardir.

Tablo 5. Öğrencilerin Okudukları Bölümlerin Bütçe Duyarlılığına Etkisi

\begin{tabular}{|c|c|c|c|c|c|}
\hline & Bölüm & Sayı & Aritmetik Ortalama & T & P \\
\hline $\begin{array}{c}\text { Bütçe } \\
\text { Duyarlı̆̆ı̆ı }\end{array}$ & Maliye & 193 & 2,5699 & \multirow{2}{*}{4,003} & 0 \\
\cline { 2 - 5 } & Diğer Bölümler & 267 & 2,3308 & \\
\hline
\end{tabular}

Bağımsız Örneklem $\mathrm{t}$ testi analiz sonuçlarına göre $\mathrm{p}=0,000<\alpha=0,05$ olduğu için $\mathrm{H}_{0}$ reddedilir, $\mathrm{H}_{1}$ kabul edilir. Çalışmaya katılan öğrencilerin okudukların bölümlerin bütçe duyarlılığına etkisi olduğu sonucuna varılır. Ankete katılan öğrencilerden Maliye Bölümü öğrencisi olanların bütçe duyarlılığı düzeyi 5'li ölçekte 2,56 olarak tespit edilirken diğer bölümlerde okuyan öğrencilerin bütçe duyarlılığı 2,33 olarak bulunmuştur. $\mathrm{Bu}$ çerçevede bir değerlendirme yapıldığında öğrencilere verilen teorik derslerin öğrencilerin Maliye Bölümü ve diğer bölümler itibarıyla farklılık göstermesi, Maliye Bölümünün müfredatının devletin mali işlemlerini ayrıntılı olarak işleyen dersleri içermesi, yine okul sonrası kamu personeli olarak istihdam edilmek isteyen öğrencilerin kamu harcamalarının türü ve yapısıyla ilgili ayrıntılı bilgilerin yer verildiği Devlet Bütçesi, Kamu Maliyesi, Devlet Borçları, Türkiye'nin Mali Yapısı, Hazine İşlemleri, Kamu Ekonomisi, Maliye Politikası gibi dersleri titizlikle takip etmesinin öğrencilerin hem kamu harcamaları hem de kamu gelirleri açısından bir farkındalık yarattığı söylenebilir.

Şüphesiz yukarıda sıralanan dersler içerisinde yer alan devlet bütçesi dersi bütçe duyarlılığını artmasında en fazla katkıyı sağlayan ders olmaktadır. Bütçenin hazırlanması, uygulanması ve denetimi ile ilgili 


\section{H.TANDIRCIOĞLU - F.YAPICI}

ayrıntılı bilgilere ulaşabilen öğrenciler kamu harcamalarındaki değişimi ve gelişimi görebilmekte orta vadeli program ve orta vadeli mali planlar hakkında bilgi sahibi olabildikleri için sadece cari yıl değil gelecek dönemle ilgili olarak fikir sahibi olabilmektedir.

Ancak tüm bunlara rağmen 5'li ölçekte Maliye Bölümü öğrencilerinin bütçe duyarlılığının 2,57 olması çok yüksek bir bütçe duyarlılığı olduğu sonucu vermemektedir. $\mathrm{Bu}$ durumun çalışmaya katılan maliye öğrencilerinin bir kısmının bütçe dersini almayan grupta yer almasından kaynaklandığg tahminlenmektedir.

Bütçe duyarlılığı ile ilgili bir diğer hipotezimiz;

$\mathrm{H}_{0}=$ Öğrencilerin bulundukları sinıfların bütçe duyarlılığına etkisi yoktur.

$\mathrm{H}_{1}=$ Öğrencilerin bulundukları sınıfların bütçe duyarlılığına etkisi vardır şeklindedir.

Tablo 6. Öğrencilerin Bulundukları Sınıfların Bütçe Duyarlılığına Etkisi

\begin{tabular}{|l|c|c|c|c|}
\hline \multicolumn{5}{|c|}{ Bütçe Duyarlılı̆̆ı } \\
\cline { 1 - 3 } & Sayı & Ortalama & F & P \\
\hline 2. sınıf & 163,00 & 2,57 & \\
\cline { 1 - 2 } 3.sınıf & 108,00 & 2,24 & \multirow{2}{*}{8,93} & 0,00 \\
\hline 4. sınıf & 189,00 & 2,42 & & \\
\hline Toplam & 460,00 & 2,43 & & \\
\hline
\end{tabular}

Tek yönlü varyans analizi sonucu elde edilen çıtılarda $p=0,000<\alpha$ $=0,05$ olduğu için $\mathrm{H}_{0}$ reddedilir, dolayısıyla $\mathrm{H}_{1}$ kabul edilir. Buna göre öğrencilerin bulundukları sınıf düzeyine göre bütçe duyarlılıkları değişmektedir. Analiz çıktısında sınıflar arasında bütçe duyarlılık düzeyinin en yüksek olduğu grubu 2. Sınıf öğrencileri $(2,57)$ oluşturmuştur. 2. Sınıf öğrencilerinden sonra bütçe duyarlılığı en yüksek olan grubu 4. Sınıf 
öğrencileri $(2,42)$ oluştururken, 3. Sınıf öğrencileri $(2,24)$ ankete katılanlar arasında bütçe duyarlılığının en düşük olduğu grup olarak tespit edilmiştir. 2. Sınıflarda bütçe duyarlılığının diğer sınıflara göre daha yüksek çıkmasının nedeni olarak öğrencilerin alan dersleriyle karşılaştıkları ilk yılda diğer alanlarda olduğu gibi bütçe duyarlılığı konusunda da ilgilerinin ve öğrenme isteklerinin daha canlı olması gösterilebilir. 3. ve 4. Sınıflardaki öğrencilerde kariyer tercihlerinin kısmi olarak belirlenmesiyle anabilim dalı farklılıkları yoğunlaşmakta ve bütçe duyarlılığı da bu çerçevede azalabilmektedir. Yapmış olduğumuz Post-hoc karşılaştırmalı çoklu Bonferroni testine göre 2. Sinıfta okuyanların 3. Sınıflara göre bütçe duyarlığının daha yüksek olduğu 0.05 güven aralığında anlamlı olarak bulunmuştur.

\subsubsection{Müdahaleci Yaklaşım}

Günümüzde kamu kesiminin Gayri Safi Milli Hasıladan (GSMH) aldığg payın büyüklüğü kamunun ekonomideki yeri ve öneminin temel belirleyicisi olarak kabul edilmektedir. GSMH' dan alınan pay ne kadar büyükse devlette o kadar müdahaleci kabul edilmektedir. Klasik iktisadi yaklaşımın kabul edildiği dönemlerde etkin işleyen bir piyasa için devletin sınırlandırılması esastı ve görünmez el piyasalarda dengeyi sağlamakta idi. Sınırlı, küçük ve denk bir bütçe ve vergilerin tarafsız olması savunulmaktaydı. 1929 Büyük buhranı ile birlikte görünmez elin başarısızlığı bir dünya krizi şeklinde kendini gösterdi. Bu esnada ekonomiye dışarıdan bir devlet müdahalesini savunan Keynezyen iktisadi yaklaşım ortaya çıktı. Keynes, hükümetlerin vergileme ve kamu harcama yetkilerini kullanarak ekonominin durgunluktan çıkmasına katkıda bulunması ve dönemsel hareketleri yumuşatması gerektiğini savunmuştur (Pınar, 2006: 15). Keynes tarafından ortaya atılan ve durgunluktan çıkıp eksik istihdam 


\section{H.TANDIRCIOĞLU - F.YAPICI}

dengesinden tam istihdam denge noktasına ulaşabilmek için başvurulan efektif talep seviyesini yükseltecek politikalar telafi edici maliye politikası olarak adlandırılmaktadır (Altay, 2016: 241). Bu politikalar Klasik iktisadın aksine kamu harcamalarını arttırmaktadır. Müdahaleci anlayışa ilişkin demografik özelliklere göre kurmuş olduğumuz hipotezler aşağıda verilmiştir.

$\mathrm{H}_{0}=$ Annenin eğitim durumunun öğrencilerin müdahaleci anlayışa sahip olmaları üzerinde bir etkisi yoktur.

$\mathrm{H}_{1}=$ Annenin eğitim durumunun öğrencilerin müdahaleci anlayışa sahip olmaları üzerinde bir etkisi vardır.

Tek yönlü varyans analizi sonuçlarına göre $p=0,043<\alpha=0,05$ olduğu için $\mathrm{H}_{0}$ reddedilir ve $\mathrm{H}_{1}$ kabul edilir. Annenin eğitim düzeyine göre lise mezunu ve ilkokul mezunu annelerin çocuklarının daha müdahaleci anlayışa sahip olduğu sonucuna varılabilir. Gruplar itibarıyla en az müdahaleci anlayışa sahip olanlar annesi okuryazar olmayanlardır. Okuryazarlık anneler arasında eğitim seviyesinin müdahaleci anlayış üzerinde esaslı farklar doğurmadığı sadece okuryazar olmanın müdahaleci anlayışı arttırdığ görülmektedir.

Tablo 7. Anne Eğitim Durumunun Müdahaleci Anlayışa Etkisi

\begin{tabular}{|l|c|c|c|c|}
\hline \multicolumn{5}{|c|}{ Müdahaleci Anlayış } \\
\cline { 1 - 3 } & Sayı & Ortalama & F & P \\
\hline Okuryazar değil & 24 & 2,9375 & & \\
\cline { 1 - 3 } İlkokul & 201 & 3,1642 & \multirow{2}{*}{2,483} & \multirow{2}{*}{0,43} \\
\hline Ortaokul & 81 & 2,9877 & & \\
\hline Lise & 124 & 3,2258 & & \\
\hline Üniversite & 30 & 3,0000 & & \\
\cline { 1 - 3 } Toplam & 460 & 3,1272 & & \\
\hline
\end{tabular}


Dokuz Eylül Üniversitesi İktisadi ve İdari Bilimler Fakültesi Dergisi

Cilt:33, Sayl:1, Yll:2018, ss. 261-292

Ancak yapmış olduğumuz Post-hoc çoklu karşılaştırma Bonferroni testine göre anne okur yazarlığındaki farklılıkların öğrencilerin müdahaleci anlayışına sahip olmasında 0,05 güven aralığında belirgin bir farklılık yaratmadığı görülmüştür.

$\mathrm{H}_{0}=$ Cinsiyetin öğrencilerin müdahaleci anlayışa sahip olmaları üzerinde etkisi yoktur.

$\mathrm{H}_{1}=$ Cinsiyetin öğrencilerin müdahaleci anlayışa sahip olmaları üzerinde etkisi vardır.

Tablo 8. Cinsiyetlerin Müdahaleci Anlayışa Etkisi

\begin{tabular}{|c|c|c|c|c|c|}
\hline \multicolumn{2}{|c|}{ Cinsiyet } & Sayı & Ortalama & T & P \\
\hline \multirow{2}{*}{ Müdahaleci anlayış } & Kadın & 253 & 3,0711 & \multirow{2}{*}{$-1,988$} & 0,047 \\
\cline { 2 - 4 } & Erkek & 207 & 3,1957 & & \\
\hline
\end{tabular}

Bağımsız örneklem $\mathrm{t}$ testi sonucuna göre $\mathrm{p}=0,047<\alpha=0,05$ olduğu için $\mathrm{H}_{0}$ reddedilir ve $\mathrm{H}_{1}$ kabul edilir. Buna göre erkeklerin kadınlara göre yaklaşık 0,12 puan daha fazla müdahaleci anlayışı benimsediğini söyleyebiliriz. Yine de p değerinin 0,05 'e oldukça yakın çıkması müdahaleci anlayış açısından cinsiyetler arasında önemli bir farklılık olmadığını göstermektedir.

\subsubsection{Eğitim}

Kamu harcama algısına etki eden faktörlerden biri olan eğitim ile ilgili kurmuş olduğumuz hipotezler aşağıda verilmiştir.

$\mathrm{H}_{0}=$ Öğrencilerin bölümleri ile kamu harcamaları hakkında bilgi sahibi olmada eğitimin etkili olduğu düşüncesi arasında ilişki yoktur.

$\mathrm{H}_{1}=$ Öğrencilerin bölümleri ile kamu harcamaları hakkında bilgi sahibi olmada eğitimin etkili olduğu düşüncesi arasında ilişsi vardır. 


\section{H.TANDIRCIOĞLU - F.YAPICI}

Tablo 9. Öğrencilerin Bölümlerine göre Eğitimin Kamu Harcamaları Algısına Etkisi

\begin{tabular}{|c|c|c|c|c|c|}
\hline \multicolumn{2}{|c|}{ Bölüm } & Sayı & Aritmetik Ortalama & T & P \\
\hline \multirow{2}{*}{ Eğitim } & Maliye & 193 & 3,3653 & \multirow{2}{*}{4,003} & \multirow{2}{*}{0,000} \\
\cline { 2 - 4 } & Diğer Bölümler & 267 & 2,9032 & & \\
\hline
\end{tabular}

Bağımsız örneklem $\mathrm{t}$ testi sonucunda elde ettiğimiz çıktıya göre $\mathrm{p}=$ $0,000<\alpha=0,05$ olduğu için $\mathrm{H}_{0}$ reddedilir, $\mathrm{H}_{1}$ kabul edilir. Buna göre öğrencilerin Maliye Bölümü ve diğer bölümlerin öğrencileri olmaları eğitimin kamu harcama algısı üzerindeki etkisi konusunda görüşlerinin farklılaştığını göstermektedir. Şöyle ki Tablo 9'a göre Maliye Bölümü öğrencilerinin $(3,36)$ ortalama sahipken diğer bölüm öğrencilerinin $(2,90)$ ortalamaya sahip olduğu görülmektedir. $\mathrm{Bu}$ farkın temel nedeni eğitim müfredatındaki farklılıktır. Kamu harcama algısı üzerinde eğitimin etkisiyle ilgili olarak belirdiğimiz bir diğer hipotez;

$\mathrm{H}_{0}=$ Öğrencilerin ailelerinin gelir düzeyi ile kamu harcama algısında eğitimin etkili olduğu düşüncesi arasında ilişki yoktur.

$\mathrm{H}_{1}=$ Öğrencilerin ailelerinin gelir düzeyi kamu harcamaları algısında eğitimin etkili olduğu düşüncesi arasında ilişki vardır.

Tablo 10. Öğrencilerin Ailelerinin Gelir Düzeyine Göre Kamu Harcama Algısında Eğitimin Etkisi

\begin{tabular}{|c|c|c|c|c|}
\hline \multicolumn{5}{|c|}{ Eğitim } \\
\hline & Sayı & Ortalama & $\mathbf{F}$ & $\mathbf{P}$ \\
\hline 1500'den az & 64 & 2,9479 & \multirow{6}{*}{2,776} & \multirow{6}{*}{0,027} \\
\hline 1500-3000'den az & 242 & 3,1522 & & \\
\hline 3500-5000'den az & 116 & 3,0690 & & \\
\hline 5000-7000'den az & 25 & 2,9533 & & \\
\hline 7000 ve üstü & 13 & 3,3333 & & \\
\hline Toplam & 460 & 3,0971 & & \\
\hline
\end{tabular}


Tek yönlü varyans analizi sonuçlarına göre $p=0,027<\alpha=0,05$ olduğu için $\mathrm{H}_{0}$ reddedilir, dolayısıyla $\mathrm{H}_{1}$ kabul edilir. Öğrencilerin ailelerinin gelir düzeyi ile eğitimin kamu harcama algısı üzerindeki etkisi üzerine düşünceleri arasında ilişki olduğunu ancak bu ilişkinin gelir düzeyleri arasında $\alpha=0,05$ düzeyinde anlamlı olmadığını söylemeliyiz.

Öğrencilerin okudukları sınıf ile kamu harcama algısında eğitimin rolü arasındaki ilişki açısından kurmuş olduğumuz hipotez;

$\mathrm{H}_{0}=$ Öğrencilerin sınıfları ile kamu harcama algısında eğitimin etkili olduğu düşüncesi arasında ilişki yoktur.

$\mathrm{H}_{1}=$ Öğrencilerin sınıfları ile kamu harcamaları algısında eğitimin etkili olduğu düşüncesi arasında ilişki vardır.

Tablo 11. Öğrencilerin Sınıflarına Göre Kamu Harcama Algısında Eğitim Etkisi

\begin{tabular}{|c|c|c|c|c|}
\hline & & & & \\
\hline & Sayı & Ortalama & $\mathbf{F}$ & $\mathbf{P}$ \\
\hline $2 . \sin 1 f$ & 163 & 3,2720 & \multirow{4}{*}{19,454} & \multirow{4}{*}{0,000} \\
\hline 3.sinif & 108 & 2,8519 & & \\
\hline 4.sinif & 189 & 3,0864 & & \\
\hline Toplam & 460 & 3,0971 & & \\
\hline
\end{tabular}

Tek yönlü varyans analizi sonuçlarına göre $p=0,000<\alpha=0,05$ olduğu için $\mathrm{H}_{0}$ reddedilir, dolayısıyla $\mathrm{H}_{1}$ kabul edilir. 2. Sınıf öğrencilerinin $(3,27)$ eğitimin kamu harcama algısı üzerinde etkisi olduğu en yüksek değerlendiren grup olurken, 4. Sınıfların $(3,08)$ ile 2. Sınıf öğrencilerinden sonra en yüksek değerlendirmede bulundukları anlaşılmaktadır. Yapmış olduğumuz Post-hoc Bonferroni çoklu karşılaştırma testi sonuçlarına göre 2. Sinıfta okuyanların kamu harcama algısı 3. Sinıfta okuyanlara göre, ve 4. Sınıfta okuyanların da 3. Sınıfta okuyanlara göre daha yüksektir; bu farklılıklar \%95 güvenle anlamlıdır. 


\section{H.TANDIRCIOĞLU - F.YAPICI}

\subsection{Kamu Harcama Algısını Etkileyen Faktörlerin Doğrusal Regresyon}

\section{Analizi}

Çalışmamız kapsamında kamu harcama algısı bağımlı değişken olmak üzere, bu algının oluşmasında etkisi test ettiğimiz iletişim düzeyi, bütçe duyarlılığı, müdahaleci anlayış ve eğitim bağımsız değişkenler olarak belirlenmişti. Yapmış olduğumuz doğrusal regresyon analizinde stepwise yöntemi kullanılmış olup, buna göre $\mathrm{R}^{2}=0,25$ olmak üzere yapmış olduğumuz analiz kamu harcama algısının \% 25'ini açıklamaktadır. Kamu harcama algısını açıklamak için oluşturulan modeller Tablo 12'de yer almaktadır.

Tablo 12. Regresyon Katsayıları

\begin{tabular}{|c|c|c|c|c|c|c|}
\hline \multicolumn{7}{|c|}{ Katsayılar $^{\mathrm{a}}$} \\
\hline & \multirow[b]{2}{*}{ Model } & \multicolumn{2}{|c|}{$\begin{array}{c}\text { Standartlaştırılmayan } \\
\text { Katsayılar }\end{array}$} & \multirow{2}{*}{$\begin{array}{c}\begin{array}{c}\text { Standartlaştırılmış } \\
\text { Katsayılar }\end{array} \\
\text { Beta }\end{array}$} & \multirow[t]{2}{*}{$\mathbf{t}$} & \multirow{2}{*}{ Sig. } \\
\hline & & B & Std. Hata & & & \\
\hline \multirow{2}{*}{1} & (Sabit) & 1,149 & 0,159 & & 7,216 & 0,000 \\
\hline & İletişim düzeyi & 0,662 & 0,059 & 0,463 & 11,166 & 0,000 \\
\hline & (Sabit) & 0,648 & 0,199 & & 3,262 & 0,001 \\
\hline 2 & İletişim düzeyi & 0,538 & 0,066 & 0,376 & 8,193 & 0,000 \\
\hline & Eğitim & 0,267 & 0,065 & 0,188 & 4,096 & 0,000 \\
\hline \multirow{4}{*}{3} & (Sabit) & 0,338 & 0,232 & & 1,456 & 0,146 \\
\hline & İletişim düzeyi & 0,507 & 0,066 & 0,354 & 7,632 & 0,000 \\
\hline & Eğitim & 0,266 & 0,065 & 0,187 & 4,100 & 0,000 \\
\hline & Müdahaleci anlayıș & 0,127 & 0,050 & 0,106 & 2,559 & 0,011 \\
\hline
\end{tabular}

Tablo 12'ye göre Model 3 seçilmekte ve bütçe duyarlılığının bir bağımsız değişken olarak kamu harcama algısı formülüne girmediği görülmektedir. Buna göre, eğer tüm bağımsız değişkenlerin 5'li ölçekte 5 değerini alması halinde kamu harcama algısı 4,8 değerini alacaktır. Yine 
bağımsız değişkenlerin tamamının 1 değerini alması durumunda kamu harcamaları algısı 1,2 değerinde olacak

$\mathrm{Y}_{\text {kamu harcaması algısı }}=0,507 *$ iletişim düzeyi $+0,266 *$ eğitim + $0,217 *$ müdahaleci anlayış

Kamu harcaması modelimize göre kamu harcama algısını en çok etkileyen faktör iletişim düzeyidir. Şöyle ki 0,507 katsayıya sahip olan iletişim düzeyi artması halinde formül içinde kamu harcama algısını bu ölçüde arttıracaktır.

\section{SONUÇ VE ÖNERILER}

Günümüz ekonomilerinde kamu kesiminin GSMH'dan aldığı payın büyüklüğü kamunun ekonomideki yeri ve öneminin temel belirleyicisi olarak kabul edilmektedir. Gerek gelişmekte olan ekonomilerde gerekse gelişmiş ekonomilerde kamu kesimi ekonomi içinde önemli bir paya sahip bulunmaktadır. Devlet halihazırda en büyük üretici ve tüketici olma özelliği yanında regülasyon ve kontroller politikası ile de milli ekonomideki belirleyici rolünü korumaktadır.

Kamu kesiminin ekonomik hayat içerisindeki rol ve sorumluluklarının artması kamu harcamalarının giderek artmasına neden olmaktadır. Siyasal karar alma sürecinde yer alan seçmenlerin daha fazla mal ve hizmet talep etmesi ve siyasetçilerin seçmen desteğini alabilmek adına bu mal ve hizmetlerin yaygınlığını ve yoğunluğunu arttırması kamu kesiminin payını arttıran bir diğer neden olmaktadır.

Kamu harcamalarının hızla arttığı bu süreçte merak edilen husus kamu harcama algısının aynı şekilde artıp artmadığıdır. Çalışmamızda kamu harcama algısı İ̈BF öğrencileri üzerinden test edilmiştir. Çalışmada siyasal karar alma süreci, kamu harcamaları, kamu gelirleri, bütçe ve mali ve 


\section{H.TANDIRCIOĞLU - F.YAPICI}

iktisadi politikalar hakkında en fazla fikre sahip oldukları varsayılan İ̈BF öğrencilerinin kamu harcamalarını nasıl algıladıkları test edilmeye çalışılmıştır. Bu bağlamda Dokuz Eylül Üniversitesi İktisadi ve İdari Bilimler Fakültesinde öğrenimine devam eden ve kolayda örnekleme yöntemi ile seçilen 460 öğrenciye uygulanan anket çalışması ile elde edilen veriler IBM SPSS Statistics (24.0) programı kullanılarak analiz edilmiştir. Çalışmada yapılan, T Testi ve Tek Yönlü Varyans Analizi (ANOVA) sonucunda elde edilen bulgular çerçevesinde ankete katılan öğrencilerin cinsiyet, yaş, aile gelir düzeyi, bölümleri, sınıfları, ailelerinin yaşadıkları yer ve ikamet ettikleri bölge açısından kamu harcamalarına yönelik algısı incelenmiştir.

Çalışmada yer alan İİBF öğrencileri maliye ve diğer bölüm öğrencileri olarak ikiye ayrılarak analiz gerçekleştirilmiştir. Maliye bölümü öğrencilerinin kamu harcamaları ve kamu gelirlerini inceleyen çok fazla ders alırken, diğer bölümlerde maliye kodlu dersler alınmakla beraber bu derslerin sayısı ve içeriğinin maliye bölümü kadar geniş kapsamlı olmaması nedeniyle bu ayırım tercih edilmiştir.

Öğrencilerin kamu harcama düzeyine ait veriler değerlendirildiğinde genel ortalamanın 2,88 olduğu ve kamu harcama algısının yüksek olmadığı görülmektedir.

Müdahaleci yaklaşım gruplandırmasına göre aritmetik ortalama 3,13 ile ortalamanın üzerinde yer almaktadır. Etkinliği sağlamak için devletin sınırlandırılması görüşü ankete katılanlar tarafından \% 46,6 geçerli yüzdeyle kabul görmemiştir. Ancak katılımcıların \% 53,4 ' ̈ü ise devletin sınırlandırılmasını kabul etmektedir. Bütün bunlar değerlendirildiğinde örneklem içinde bulunan DEÜ İIBF öğrencilerinde sosyal devlet anlayışının genel kabul gördüğü ancak etkinliğin de göz ardı edilmediği görülmektedir. 
Çalışmaya katılan öğrencilerin kamu harcama algısını belirleyen faktörler cinsiyetler açısından değerlendirildiğinde dikkate değer bir farklılık tespit edilmemiştir.

Kamu harcama algısına etki eden faktörlerden bütçe duyarlılığında Maliye Bölümü öğrencilerinin alg1 düzeyi 5'li ölçekte 2,56 olarak tespit edilirken diğer bölümlerde okuyan öğrencilerin bütçe duyarlılığg 2,33 olarak bulunmuştur. $\mathrm{Bu}$ çerçevede bir değerlendirme yapıldığında Maliye Bölümünde okuyan öğrencilerin hem kamu harcamaları hem de kamu gelirleri açısından daha ayrıntılı bilgiler içeren dersleri aldığı ve bu durumun bütçe duyarlılı̆̆ üstünde olumlu bir etkisi olduğu yorumu yapılabilir. Öğrencilerin okudukları bölüme göre eğitim ve kamu algısı arasındaki ilişki konusunda görüşleri farklılaşmaktadır. Yapmış olduğumuz bağımsız örneklem t testine göre Maliye Bölümü öğrencileri $(3,36)$ ortalamaya sahipken diğer bölüm öğrencilerinin $(2,90)$ ortalamaya sahip olduğu görülmüş ve dolayısıyla Maliye Bölümü öğrencilerinin eğitimin etkisi konusunda daha olumlu görüşe sahip olduğu anlaşılmıştır. Öğrencilerin yaşlarına göre iletişim düzeyi hakkındaki düşüncelerinin değiştiği görülmüş, iletişim düzeyi üzerine en yüksek algıya sahip olan öğrencilerin 18-22 yaş grubunda olduğu gözlemlenmiştir.

Kamu harcama algısına etki eden faktörlerin kendi aralarındaki ilişkiye bakıldığında eğitim ile bütçe duyarlılığı arasında korelasyon katsayısı r=0,544 bulunmuş olup, bu oran \% 99 güvenle anlamlıdır. Yine iletişim ile bütçe duyarlılığı arasında korelasyon katsayısı r=0,491 olup, bu oran \% 99 güvenle anlamlıdır. İletişim ile kamu harcama algısı arasında korelasyon katsayısı r=0,461'dir ve aralarındaki ilişki pozitif yönlüdür. 


\section{H.TANDIRCIOĞLU - F.YAPICI}

Kamu harcama algısına etki eden faktörlerin kamu harcama algısına etki derecesini tespit etmek amacıyla yaptığımız doğrusal regresyon analizine göre seçmiş olduğumuz model;

$\mathrm{Y}_{\text {kamu harcaması algısı }}=0,507 *$ iletişim düzeyi $+0,266 *$ eğitim + 0,217*müdahaleci anlayış olmak üzere, kamu harcama algısında en belirleyici faktörün iletişim düzeyi olduğu tespit edilmiştir.

Bugün Türkiye'de kamu mali yönetimini düzenleyen ve uyulması gerekli temel usul ve esasların çerçevesini çizen 5018 Sayılı Kamu Mali Yönetimi ve Kontrol Kanunu kamusal kaynakların kullanımı ve kamusal mal ve hizmetlerin en etkin ve verimli yöntemlerle üretilmesi konusunda kamu idareleri için bağlayıcı oldukça önemli ilkeler ortaya koymaktadır. $\mathrm{Bu}$ çerçevede Kanunun 7. Maddesi mali saydamlıkla ilgili hükümlere yer vermiştir. Madde 7'ye göre “Her türlü kamu kaynağının elde edilmesi ve kullanılmasında denetimin sağlanması amacıyla kamuoyu zamanında bilgilendirilir...” . Bütçe ilkelerini düzenleyen 13. Madde’de “Bütçe, kamu mali işlemlerinin kapsamlı ve saydam bir şekilde görünmesini sağlar... Bütçe gelir ve gider tahminleri ile uygulama sonuçlarının raporlanmasında açıklık, doğruluk ve malî saydamlık esas alınır." hükümleri yer almaktadır. Kamu mali yönetiminde esas alınan mali saydamlık prensibi modern bir ilke olarak kamu idarelerinin her türlü faaliyet ve işlemlerine ilişkin tahminlerin, uygulamaların ve uygulama sonuçlarının kamuoyu ile doğru ve zamanında olmak üzere belirli usuller dâhilinde paylaşılmasını gerektirmektedir. Gerek yazılı gerekse görsel medyada da mali saydamlığı güçlendirecek bilgiler yer alabilmektedir. Ankete katılan öğrencilerin iletişim düzeyine değer atfetmeleri bu süreçlerden kaynaklanmaktadır. Buna göre öğrencilerin kamu harcama algısını arttıran bir faktör olarak iletişim düzeyinin etkisinin yüksekliği açıklamalarımızla örtüşmektedir. 


\section{KAYNAKÇA}

AKDOĞAN, A. (2011), Kamu Maliyesi, Gazi Kitabevi, Ankara.

AKTAN, C.C. ve DİLEYİCİ, D. (2014), 'Kamu Ekonomisindeki Etkinsizliklerin Kaynakları', Kamu Ekonomisi I, (Ed. C.C. Aktan ve D. Dileyici), T.C. Anadolu Üniversitesi Yayını No: 2703, Eskişehir, 78-105.

AKTAN, C.C., DİLEYİCI, D. Ve VURAL, İ.Y. (2006). Vergileme Ekonomisi ve Vergileme Psikolojisi. Seçkin Yayıncılık, Ankara.

ALTAY, A. (2016). Kamu Maliyesi Teorisi Gelişimi Kapsamı, Seçkin Yayınevi, 2. Basım.

ÇEVİK, S.(2012), Mükellefin Devlet ve Toplumla Etkileşimi, Bireysel Normlar ve Vergi Ahlak1, Maliye Dergisi, 209 (163), 258-289.

ÇIÇEK, H., KARAKAŞ, M. Ve YILDIZ, A. (2008). Güneydoğu Anadolu Bölgesi’nde Vergi Yükümlülerinin Vergiyi Algılama ve Tutum Analizi: Bir Alan Araştırması, T.C. Maliye Bakanlığı Strateji Geliştirme Başkanlığı, Yayın No: 2008/ 381, Ankara.

ÇİÇEK, H. (2006), Psikolojik ve Sosyal Yönden Yükümlülerin Vergiye Karşı Tutum ve Tepkileri. T.C. İstanbul Üniversitesi Sosyal Bilimler Enstitüsü Maliye Anabilim Dalı Doktora Tezi, İstanbul.

DEVRİM, F.(1998), Kamu Maliyesine Giriş, İzmir.

DEMIR, İ., C. (2009), "Kamusal Harcamaların Toplumsal Algıs1: Amprik Bir Araştırma", Maliye Dergisi, 157, Temmuz-Aralık, 210-226.

EKER, A. (2009), Kamu Maliyesi, Birleşik Matbaa, İzmir.

ÖMÜRBEK, N, ÇİÇEK, H.,G., ÇIÇEK, S. (2007), "Vergi Bilinci Üzerine Bir İnceleme: Üniversite Öğrencileri Üzerinde Yapılan Anketin Bulguları", Maliye Dergisi, 153,Temmuz-Aralık, 102-122.

KARAKAŞ, M. ve ÇIÇEK, H. (2009), "Vergi Yükümlülerinin Yolsuzluğa İlişkin Tutum ve Tepkileri: Gaziantep Örneği", Sosyoekonomi Dergisi, 2009 (1), 47-76. 


\section{H.TANDIRCIOĞLU - F.YAPICI}

MUTER, N., SAKINÇ S., ÇELEBİ K.(1993), Manisa İli Vergi Mükellefleri Üzerine Bir Anket Çalışması, Celal Bayar Üniversitesi, İ̈BF, Maliye Bölümü. Manisa.

PATINKIN, D. (1984), “Keynes and Economics Today”, The American Review, 74 (2), Papers and Proceedings of the Ninety-Sixth Annual Meeting of the American Economic Association , May, 97-102. www.jstor.org/Stanley/1816337

PINAR, A. (2006), Maliye Politikası Teori ve Uygulama, Naturel Yayınc1lik, Ankara.

SAĞBAŞ, İ. ve BAŞOĞLU, A (2005), İlköğretim Çağındaki Öğrencilerin Vergileri Algılaması;Afyonkarahisar İli Örneği, Afyon Kocatepe Üniversitesi, İ.I. B.F. Dergisi, 7 (2), 123-144.

SIVEREKLİ E., ERTUĞRUL, H.G.,(2016), Misafirlikten Diasporaya Doğru: Suriyeli Sığınmacıların Vergi Algısı Üzerindeki Etkisine Yönelik Bir İnceleme, Yönetim Bilimleri Dergisi, 14 (27), 491-518.

TÜĞEN, K. (2017), Devlet Bütçesi, Bassaray Matbaası, İzmir.

WALKINS, J., P. (2010), "Rescuing the Renter-Neoliberalism, Social Imbalance, and the Current Crisis : A Synthesis of Keynes, Galbraith and Minsky”, Journal of Economic Issues, (May, 1984), 97-102. www.jstor.org/stable/20778690

YAY G., G. (2001), "Chicago Okulu Milton Friedman ve Monetarizm”, Liberal Düşünce, Güz , 6(24), 196-207.

YILDIZ, F. ve ALKAN, F.(2017), Katılımcı Bütçeleme Perspektifinden Yükseköğretim Öğrencilerinin Bütçe Algısı Araștırması: Dumlupınar Üniversitesi Örneği, Maliye Araşstırmaları Dergisi, 3 (2),129-145. 